7. Закон України про державні фінансові гарантії медичного обслуговування населення. URL: http://zakon.rada.gov.ua/laws/show/2168-19.

8. Основи законодавства України про охорону здоров’я. URL: http://zakon.rada.gov.ua/laws/ show/2801-12.

9. Розпорядження Кабінету Міністрів України Про схвалення Концепції реформи фінансування системи охорони здоров'я. URL: http://zakon3.rada.gov.ua/laws/show/1013-2016-p.

10. Постанова Кабінету Міністрів України Про затвердження переліку платних послуг, які надаються в державних і комунальних закладах охорони здоров'я та вищих медичних навчальних закладах. URL: http://zakon.rada.gov.ua/laws/show/1138-96-п.

11. Постанова Кабінету Міністрів України Про деякі питання державного регулювання цін на лікарські засоби і вироби медичного призначення. URL: http://zakon.rada.gov.ua/laws/ show/333-2009-п\#n15.

12. Постанова Кабінету Міністрів України Про Деякі питання щодо договорів про медичне обслуговування населення за програмою медичних гарантій. URL: http://zakon.rada.gov.ua/ laws/show/410-2018-п\#n15.

13. Міністерство охорони здоров'я України. URL: https://m.facebook.com/story.php?story_ fbid $=1137800963049674 \&$ id=261889753974137.

УДК 342.9

DOI https://doi.org/10.32844/2618-1258.2019.3-1.14

БУДЗИнСькИй М.П.

\title{
ПРИНЦИПИ АДМІНІСТРАТИВНО-ПРАВОВОГО РЕГУЛЮВАННЯ У СФЕРІ КАДРОВОГО ЗАБЕЗПЕЧЕННЯ НАЦІОНАЛЬНОЇ ПОЛЮЦЇ̈ УКРАЇНИ
}

На основі аналізу сучасних теоретичних уявлень про сутність принципів адміністративно-правового регулювання сформульовано авторське визначення поняття «принципи адміністративно-правового регулювання у сфері кадрового забезпечення Національної поліції України», під яким запропоновано розуміти керівні, фундаментальні основи (основоположні засади), які зумовлюють сутність і значення кадрового забезпечення, характеризують його зміст, форми й методи діяльності спеціально уповноважених суб'єктів щодо забезпечення органів і підрозділів Національної поліції України кваліфікованими кадрами з необхідним рівнем професійних та особистих якостей, здатними ефективно виконувати покладені на них обов'язки щодо забезпечення охорони прав і свобод людини, інтересів суспільства і держави, протидії злочинності, підтримання публічної безпеки і порядку.

Обгрунтовано, що до них належать: 1) загальні принципи (верховенство права, дотримання прав і свобод людини, законності, відкритості та прозорості, політичної нейтральності, взаємодії тощо); 2) спеціальні принципи (цілеспрямованість, професіоналізм і компетентність, індивідуальний підхід та індивідуальна відповідальність, плановість і прогнозування, підзвітність, демілітаризація, неупередженість, об'єктивність-тощо).

Зазначено, що мета будь-якої системи принципів, у тому числі принципів адміністративно-правового регулювання у сфері кадрового забезпечення Національної поліції України, - це досягнення гармонізації правового регулювання, тобто упорядкування правових норм таким чином, щоб їхній зміст був максимально взаємоузгоджуваним і відповідав типу суспільних відносин, які виникають у процесі діяльності із забезпечення органів Національної поліції України кваліфікованими кадрами, здатними виконувати покладені на них обов'язки.

БУДЗИНСьКИЙ М.П. - кандидат юридичних наук, т. в. о. заступника директора (Державний науково-дослідний інститут Міністерства внутрішніх справ України) 
Наголошено, що наразі у чинному законодавстві України, зокрема й у відомчих нормативно-правових актах МВС України та Національної поліції України, не закріплено принципів кадрового забезпечення. У зв'язку із цим, а також зважаючи на те, що правові норми, які регулюють кадрову роботу, повинні гармонійно поєднуватися 3 домінуючими суспільними цінностями та концепцією реформування системи МВС України, а реалізація принципів як основоположних засад кадрового забезпечення Національної поліції України має сприяти успішному здійсненню функцій, вирішенню завдань із охорони прав і свобод людини, інтересів суспільства і держави, доведено доцільність нормативного закріплення спеціальних принципів, а саме: індивідуального підходу та індивідуальної відповідальності; плановості та прогнозування; неупередженості, об'єктивності.

Ключові слова: забезпечення, кадрове забезпечення, адміністративно-правове регулювання, кадри, проходження служби, Національна поліція України, принципи.

Based on the analysis of modern theoretical concepts of the essence of the principles of administrative-legal regulation the author's definition of the concept of "principles of administrative and legal regulation in the sphere of staffing of the National Police of Ukraine" is formulated. The definition should be considered as a guiding, fundamental basis (basic principles), which determine the essence and the importance of staffing, characterizing its content, forms and methods of activity of specially authorized subjects for ensuring the bodies and units of the National Police of Ukraine with qualified personnel with the necessary level of professional and personal qualities, capable of effectively fulfilling their duties to ensure the protection of human rights and freedoms, the interests of society and the state, countering crime, and maintaining public safety and order.

They include the following: 1) general principles (rule of law, safeguarding the freedoms and rights of persons, legality, openness and transparency, political neutrality, interaction, and the like);2) specific principles (commitment, professionalism and competence, individual approach and individual responsibility, planning and forecasting, accountability, demilitarization, impartiality, objectivity, etc.).

It was noted that the purpose of any system of principles, including the principles of administrative and legal regulation in the field of staffing of the National Police of Ukraine - harmonization of legal regulation, namely, streamlining of legal norms in such a way that their content is mutually agreed and corresponded to the type of social attitudes that arise in the process of providing the bodies of the National Police of Ukraine with qualified personnel capable of performing their duties.

It was pointed out that current Ukrainian legislation, in particular the departmental regulations of the Ministry of Internal Affairs and the National Police, does not enshrine the principles of staffing. With that in mind, as well as taking into account the fact that the legal norms regulating the personnel work should be harmoniously combined with the dominant social values and the concept of reforming the system of the Ministry of Internal Affairs of Ukraine, and the implementation of the principles as the fundamental concepts of the personnel support of the National Police of Ukraine should contribute to the successful implementation of the functions, the solution of the tasks on protection of human rights and freedoms, the interests of the society and the state, it has been proved the expediency of the normative fixation of special principles, namely: individual approach and individual responsibility; planning and forecasting; impartiality, objectivity.

Key words: ensuring, staffing, administrative and legal regulation, staff, service, the National Police of Ukraine, principles.

Вступ. Ефективність адміністративно-правового регулювання у сфері кадрового забезпечення Національної поліції України зумовлюється, насамперед, науковою обгрунтованістю елементів, що відображають його сутність та внутрішню будову, ключовими 3 яких є принципи адміністративно-правового регулювання у цій сфері.

Дослідженням зазначеної проблематики займалися такі вчені, як: С.О. Андренко, М.І. Ануфрієв, О.М. Бандурка, М.М. Дивак, К.С. Ізбаш, Л.С. Кацалап, А.М. Клочко, В.О. Криволапчук, 
В.О. Кудря, В.М. Мельникович, В.М. Плішкін, О.Ю. Синявська, В.М. Чупров та інші науковці, у працях яких були висвітлені питання щодо принципів кадрового забезпечення органів внутрішніх справ, але вони не враховують сучасний етап організаційних і законодавчих змін, які актуалізувалися у зв'язку з обранням нашою країною європейського напряму свого розвитку. Необхідність проведення дослідження зазначених питань для правозахисної діяльності Національної поліції України відіграє важливу роль під час виконання поліцейськими обов'язків щодо забезпечення охорони прав і свобод людини, протидії злочинності, підтримання публічної безпеки і порядку, що і вступає метою даної статті.

Результати дослідження. Погоджуючись з С.О. Андренко [1, с. 46-47], необхідно зазначити, що принципи адміністративно-правового регулювання у сфері кадрового забезпечення Національної поліції тісно пов'язані із принципами функціонування даного інституту в системі державного управління й при цьому характеризують специфіку кадрового забезпечення. Якщо розглядати поняття «принцип» із погляду загальновживаного, літературного значення, то під ним слід розуміти як правило, норму, якою керується хто-небудь у житті, поведінці [2, с. 436]. В юридичній енциклопедії під принципами розуміються основні засади, вихідні ідеї, що характеризуються універсальністю, загальною значущістю, вищою імперативністю і відображають суттєві положення теорії, вчення, науки [3, с. 110].

Г.В. Атаманчук вважає, що принцип відображає в системі державного управління закономірності, відносини, взаємозв'язки між іiї елементами. Разом із цим він зазначає, що принцип це специфічне поняття, в якому міститься не стільки закономірність, відносини, взаємозв'язок, скільки наше знання про них $[4$, с. 186]. В. К. Колпаков наголошує, що принципи - це науково обгрунтовані та практично закріплені у відповідних термінологічних категоріях позитивні закономірності [5, с. 20].

Не можна не погодитися з позицією П.М. Рабіновича, що принципами є керівні засади (ідеї), які зумовлюються об'єктивними закономірностями існування та розвитку людини і суспільства і визначають зміст та спрямованість правового регулювання [6, с. 82].

Незважаючи на те, що дослідженню питань щодо принципів правового регулювання присвячені праці А.І. Бобильова, Т.О. Затолокіної, А.М. Колодія, М.Ю. Осипова, Р.Л. Іванова, К.П. Уржинського та інших вчених, треба сказати, що наразі вітчизняні та зарубіжні наукові праці, присвячені дослідженню загальнотеоретичної моделі принципів правового регулювання як самостійної юридичної категорії, відсутні. Як наслідок, принципи правового регулювання не вважаються самостійним юридичним явищем, яке має реальне значення, i продовжують за традицією залишатися практично недослідженою другорядною категорією, ані властивості, ані ознаки та значення якої дотепер повною мірою не досліджені. Водночас, як справедливо наголошує Н.О. Саглаєва, принципи правового регулювання слід розглядати як базові теоретичні моделі, система специфічних нормативно-правових регулятивних засобів яких залучається до багатьох конкретних механізмів правового регулювання в залежності від специфіки предмета та мети правового регулювання [7, с. 192]. Разом із цим, на думку С.Г. Стеценка, принципами правового регулювання можуть вважатися керівні ідеї, передумови, які можуть бути використані як базис для побудови норм права [8, с. 388].

Що стосується безпосередньо принципів кадрового забезпечення, то хотілося б відзначити думку Т.С. Кагановської, яка стверджує, що принципи кадрового забезпечення обов'язково мають мати юридичну природу та зміст, повинні втілюватися в структурних елементах механізму правового регулювання та знайти свій прояв у: 1) нормах адміністративного права; 2) адміністративному законодавстві, яке $є$ зовнішньою формою змісту правових норм; 3) управлінських правовідносинах, які є формою реалізації повноважень суб'єктів кадрового забезпечення [9, с. 31-33].

Отже, як бачимо, принципи адміністративно-правового регулювання відображають керівні, фундаментальні основи (основоположні засади), які визначають зміст і спрямованість тієї чи іншої діяльності (сфери, галузі, інституту). Серед їхніх основних особливостей варто виділити те, що вони є постійними і мають обов'язковий характер; закріплені, як правило, в правових нормах; взаємопов'язані між собою і відображають специфіку відповідної діяльності (сфери, галузі).

Таким чином, на підставі зазначеного вище вважаємо, що під принципами адміністративно-правового регулювання у сфері кадрового забезпечення Національної поліції України слід розуміти керівні, фундаментальні основи (основоположні засади), які визначають сутність та значення кадрового забезпечення, характеризують його зміст, а також визначають форми та методи діяльності спеціально уповноважених суб'єктів щодо забезпечення органів та підрозділів Національної поліції України кваліфікованими кадрами з необхідним рівнем професійних та осо- 
бистих якостей, здатними ефективно виконувати покладені на них обов'язки щодо забезпечення охорони прав і свобод людини, інтересів суспільства і держави, протидії злочинності, підтримання публічної безпеки і порядку.

Варто підкреслити, що метою будь-якої системи принципів, у тому числі принципів адміністративно-правового регулювання у сфері кадрового забезпечення Національної поліції України, є досягнення гармонізації правового регулювання, тобто упорядкування правових норм таким чином, щоб їхній зміст був максимально взаємоузгоджуваним і відповідав типу суспільних відносин, які виникають у процесі здійснення діяльності щодо забезпечення органів Національної поліції України кваліфікованими кадрами, здатними виконувати покладені на них обов'язки.

Необхідно підкреслити, що серед науковців немає одностайної думки щодо класифікації принципів у цій сфері. Так, I.М. Шопіна, наприклад, виділяє такі групи принципів адміністративно-правового регулювання управління ОВС як керівних ідей, що можуть бути основою для побудови норм права: системні, які призначені забезпечувати внутрішню єдність права, підтримувати стійкі зв'язки між правовими нормами (загальноправові, міжгалузеві, галузеві, а також принципи інститутів адміністративного права), принципи правотворчості, правореалізації і правоохорони [10, с. 12].

Однак варто констатувати, що більшість науковців розрізняють, як правило, загальні принципи (тобто ті, що притаманні будь-якій управлінській діяльності в суспільстві) та спеціальні (тобто ті, що враховують специфіку того чи іншого державного інституту та його адміністративно-правовий статус). Підтримуючи цю позицію, перейдемо до розгляду загальних та спеціальних принципів адміністративно-правового регулювання в досліджуваній нами сфері.

Розглядаючи загальні принципи адміністративно-правового регулювання у сфері кадрового забезпечення Національної поліції України, перш за все, доцільно звернути увагу на принципи державної служби, оскільки служба в поліції, згідно із ч. 1 ст. 59 Закону України «Про Національну поліцію», $є$ державною службою особливого характеру [11], а Національна поліція України, насамперед, $є$ органом державної влади, діяльність якої так чи інакше повинна відповідати загальноприйнятим стандартам у сфері проходження державної служби.

Принципи державної служби закріплені у ст. 4 Закону України «Про державну службу» від 10.12.2015 № 889-VIII, відповідно до якої державна служба здійснюється 3 дотриманням таких принципів: верховенства права; законності; професіоналізму; патріотизму; доброчесності; ефективності; забезпечення рівного доступу до державної служби; політичної неупередженості; прозорості; стабільності [12]. У той же час Закон України «Про Національну поліцію» в Розділі II (ст.ст. 6-12) закріпив положення про те, що поліція (у т.ч. й підрозділи кадрового забезпечення та їхні посадові особи) у своїй діяльності керується такими принципами: верховенство права (ст. 6); дотримання прав і свобод людини (ст. 7); законність (ст. 8); відкритість та прозорість (ст. 9); політична нейтральність (ст. 10); взаємодія з населенням на засадах партнерства (ст. 11); безперервність (ст. 12) [11].

На підставі зазначеного можна стверджувати, що до загальних принципів адміністративно-правового регулювання у сфері кадрового забезпечення Національної поліції України відносяться:

1) принцип верховенства права як основа правової системи демократичного суспільства поширюється на всі правовідносини і означає, що людина, іiї права та свободи визнаються найвищими соціальними цінностями, які визначають зміст і спрямованість будь-якої діяльності держави (у т.ч. й діяльності спеціально уповноважених суб'єктів щодо забезпечення органів та підрозділів Національної поліції України кваліфікованими кадрами з необхідним рівнем професійних та особистих якостей, здатними ефективно виконувати покладені на них обов'язки);

2) принцип дотримання прав і свобод людини, який зумовлює такий характер функціонування Національної поліції України, за якого ііі кадри спрямовували б свою діяльність безпосередньо на втілення в життя прав і свобод людини, гарантованих Конституцією та законами України, а також міжнародними договорами України, згода на обов'язковість яких надана Верховною Радою, і сприяли їхньої реалізації;

3) принцип законності, відповідно до якого: а) всі кадри Національної поліції України зобов'язані діяти виключно на підставі, в межах повноважень та у спосіб, що визначені Конституцією та законами України; б) їм заборонено виконувати злочинні чи явно незаконні розпорядження та накази; в) накази, розпорядження та доручення вищих органів, керівників, посадових та службових осіб, службова, політична, економічна або інша доцільність не можуть бути підставою для порушення кадрами Національної поліції України Конституції та законів України; 
4) принцип відкритості та прозорості, який передбачає, що: а) поліція забезпечує постійне інформування органів державної влади та органів місцевого самоврядування, а також громадськості про свою діяльність у сфері забезпечення органів та підрозділів Національної поліції України кваліфікованими кадрами з необхідним рівнем професійних та особистих якостей, здатними ефективно виконувати покладені на них обов'язки; б) поліція забезпечує доступ до публічної інформації, володільцем якої вона $\epsilon$, в порядку та відповідно до вимог, визначених законом; в) поліція може оприлюднювати (поширювати) інформацію з обмеженим доступом лише у випадках та в порядку, визначених законом; г) нормативно-правові акти, що регламентують діяльність поліції, обов'язково оприлюднюються на веб-порталі центрального органу управління поліції; г) проекти нормативно-правових актів, що стосуються прав та свобод людини, обов'язково проходять громадське обговорення в порядку, визначеному Міністром внутрішніх справ України.

У цьому контексті слід звернути увагу на те, що відповідно до Принципів Європейського адміністративного простору (SIGMA-1999) принцип відкритості та прозорості розуміється як: відкритість на противагу секретності; прозорість на противагу дискретності; винятковість конфіденційного та секретного характеру діяльності органів публічної влади; набрання законної сили тільки після офіційного опублікування; підлеглість публічних адміністрацій зовнішньому контролю; обов'язкове обгрунтування та наведення підстав прийнятого рішення особі, чиї права або законні інтереси зачіпаються з його прийняттям [13];

5) принцип політичної нейтральності, згідно з яким: а) поліція забезпечує захист прав та свобод людини незалежно від політичних переконань та партійної належності; б) поліція у своїй діяльності є незалежною від рішень, заяв чи позицій політичних партій та громадських об'єднань; в) в органах і підрозділах поліції заборонено використовувати будь-які предмети, на яких зображена символіка політичних партій, та провадити політичну діяльність; в) поліцейським заборонено висловлювати особисте ставлення до діяльності політичних партій під час виконання службових повноважень, а також використовувати службові повноваження в політичних цілях;

6) принцип взаємодії, який передбачає, що діяльність поліції (у т.ч. й підрозділів кадрового забезпечення та їхніх посадових осіб) здійснюється в тісній співпраці та взаємодії з населенням, територіальними громадами та громадськими об'єднаннями на засадах партнерства тощо.

Дослідження й аналіз чинного законодавства України та наукових праць вчених дозволяє стверджувати також про наявність й інших (спеціальних) принципів, які за своїм характером і змістом безпосередньо враховують специфіку адміністративно-правового регулювання у сфері кадрового забезпечення Національної поліції України. Так, наприклад, принципи реформування органів внутрішніх справ з урахуванням позитивного світового досвіду та реалій сьогодення знайшли своє відображення у Стратегії розвитку ОВС [14], серед яких (окрім згаданих вище принципів верховенства права, деполітизації; підзвітності та прозорості в роботі, а також тісної співпраці з населенням та місцевими громадами) окремо виділяються два принципи, які не відображені у Законі України «Про Національну поліцію», а саме принципи демілітаризації та професійної підготовки персоналу (або професіоналізму та компетентності).

Зазначені принципи, на нашу думку, мають пряме відношення й до принципів здійснення кадрового забезпечення Національної поліції. Так, принцип демілітаризації поліції - це необхідна складова частина нової філософії, організації, підготовки, навчання та функціонування кадрів Національної поліції, що набуває особливого значення в контексті європейської інтеграції України. Як слушно зазначає В. Жмінько, «ігнорування важливості демілітаризації поліції може зумовити значну небезпеку і стати на заваді демократизації правоохоронних органів... безпосередня участь працівників правоохоронних органів у бойових діях, поза сумнівом, впливатиме на процес реформування в Україні та може спричиняти збереження воєнізованого характеру міліції і затримати процес іiї демілітаризації на невизначений термін. Поліція має зберігати демілітаризований характер навіть за умов воєнного часу...» [15, с. 104].

Слід підкреслити, що зазначений принцип передбачений відповідними міжнародними стандартами щодо діяльності органів забезпечення правопорядку. Так, Рада Європи розробила стандарти щодо статусу поліції, поліцейських та порядку виконання ними повноважень, зокрема, поліція є не військовим формуванням, а службою, яка надає суспільству і окремим його представникам допомогу та послуги щодо забезпечення безпеки і правопорядку. Статус поліцейських характеризується таким: поліцейські є публічними службовцями, а не військовослужбовцями; звання офіцерів поліції є спеціальними, тобто відмінні від військових звань. У зв'язку із цим необхідно погодитись, що реалізація в Україні зазначених європейських стандартів має перетворити військові, централізовані, політично залежні формування міліції в поліцейську публічну 
службу, орієнтовану на інтереси громад, яка діятиме під координацією й управлінням цивільного $\operatorname{MBC}[16$, c. 7$]$.

Принцип професіоналізму та компетентності у сфері адміністративно-правового регулювання у сфері кадрового забезпечення Національної поліції випливає зі змісту основних положень Закону України «Про Національну поліцію», згідно з якими: одним із основних обов'язків поліцейського є професійне виконання своїх службових обов'язків відповідно до вимог нормативно-правових актів, посадових (функціональних) обов'язків, наказів керівництва (п. 2 ч. 1 ст. 18); добір (конкурс) та просування за службою поліцейських постійними поліцейськими комісіями проводиться на підставі, перш за все, об'єктивного оцінювання професійного рівня кожного поліцейського (ч. 1 ст. 51); проведення конкурсу на прийняття на службу та зайняття вакантної посади здійснюється, зокрема, з урахуванням рівня професійної компетентності кандидатів (ч. 2 ст. 52); атестування поліцейських проводиться з метою оцінки їхніх професійних якостей (ч. 1 ст. 57); служба в поліції є державною службою особливого характеру, яка є професійною діяльністю поліцейських із виконання покладених на поліцію повноважень (ч. 1 ст. 59) тощо [11].

В юридичній літературі поняття «професіоналізм» розглядається як глибоке і всебічне знання і володіння практичними навичками в певній галузі суспільної діяльності. Так, С.В. Ківалов і Л.Р. Біла вважають, що «професіоналізм» зобов'язує: бути постійно готовими до здійснення посадових повноважень; добре знати предмет власної державно-службової діяльності; знати свої обов'язки і права, повною мірою і якісно здійснювати функції і повноваження, передбачені законодавством і посадовими положеннями та інструкціями; володіти правилами і процедурами діяльності в державних органів; мати загальну і спеціальну професійну підготовку; знати юридичні і морально-етичні норми у сфері державної служби [17, с. 19].

Що стосується принципу компетентності, то варто наголосити, що за своїм смисловим значенням він ототожнюється з наведеним принципом професіоналізму, оскільки під словом «компетентний», як правило, розуміють: «1) який має достатні знання в якій-небудь галузі; який із чим-небудь добре обізнаний; тямущий; який грунтується на знанні; кваліфікований; 2) який має певні повноваження; повноправний, повновладний» [18, с. 874].

Аналіз чинного законодавства України, що регулює діяльність Національної поліції, дає підстави стверджувати, що держава окреслює межі компетентності осіб, які висуваються до кадрів Національної поліції України. Невідповідність встановленим критеріям позбавляє їх зазначеного статусу. До критеріїв компетентності кадрів поліції слід віднести такі вимоги, які пред’являються до поліцейських та кандидатів на службу в поліції: поліцейським може бути громадянин України, який склав Присягу поліцейського, проходить службу на відповідних посадах у поліції і якому присвоєно спеціальне звання поліції (ч. 1 ст. 17); на службу в поліцію можуть бути прийняті громадяни України віком від 18 років, які мають повну загальну середню освіту, які володіють українською мовою (ч. 1 ст. 49); громадяни України, які виявили бажання вступити на службу в поліції, зобов'язані пройти медичні обстеження, а також перевірку рівня фізичної підготовки, психофізіологічне обстеження, обстеження на предмет виявлення алкогольної, наркотичної та токсичної залежності в порядку, визначеному МВС України (ч. 1 ст. 50); щодо осіб, які претендують на службу в поліції, проводиться спеціальна перевірка, порядок проведення якої визначається законом та іншими нормативно-правовими актами (ч. 3 ст. 50); особи, які бажають взяти участь у конкурсі на посаду поліцейського, подають у визначеному порядку до поліцейської комісії відповідні документи (копії паспорта громадянина України, документів про освіту, трудової книжки, військового квитка або посвідчення особи військовослужбовця, автобіографію та ін.) тощо (ст. 54) [11].

Крім того, професіоналізмом та компетентністю мають володіти також й уповноважені суб'єкти у сфері кадрового забезпечення Національної поліції України. Так, на нашу думку, працівники, наприклад, Департаменту кадрового забезпечення Національної поліції України для ефективного забезпечення реалізації державної політики з питань кадрової роботи та державної служби в апараті Національної поліції України, територіальних (міжрегіональних) органах Національної поліції України під час здійснення своєї діяльності безперечно повинні: володіти знаннями законів України, указів і розпоряджень Президента України, постанов і розпоряджень Уряду, нормативних актів обласних, Київської та Севастопольської міських державних адміністрацій; застосовувати у своїй діяльності норми як матеріального, так і процесуального права, а саме нормативно-правові акти галузевого (трудового, адміністративного, цивільного) законодавства для врегулювання конкретних правовідносин, тому мають бути обізнаними в тих змінах, які вносяться у це законодавство; володіти комп'ютерною грамотою, бути кваліфікованим користувачем 
мережі Інтернет для упровадження сучасних методів і новітніх форм організації праці та управління в діяльність підрозділів кадрового забезпечення, надання їм практичної допомоги із цих питань тощо.

Отже, професіоналізм та компетентність виступають як якість (характеристика), що дозволяє вирішувати конкретні завдання в процесі добору кадрів, проходження служби в поліції, професійної підготовки та підвищення кваліфікації кадрів, атестування, формування кадрового резерву, переміщення поліцейських в органах та підрозділах Національної поліції України, перебування поліцейських у розпорядженні, звільнення зі служби в поліції тощо.

Вважаємо також, що сучасна специфіка адміністративно-правового регулювання у сфері кадрового забезпечення Національної поліції базується на таких принципах, як: 1) принцип цілеспрямованості, який означає, що діяльність уповноважених суб'єктів безпосередньо спрямована на досягнення загальної мети, а саме на забезпечення органів та підрозділів Національної поліції України кваліфікованими кадрами з необхідним рівнем професійних та особистих якостей, здатними ефективно виконувати покладені на них обов'язки. Застосування цього принципу вимагає від уповноважених суб'єктів знання мети кадрового забезпечення Національної поліції України, уміння в конкретній ситуації ставити оптимальні завдання для досягнення цієї мети, враховуючи професійні та особисті якості окремих кадрів Національної поліції України; 2) принцип індивідуальної відповідальності кожного окремого працівника як за вчинення ним протиправних, неправомірних діянь, так і за неналежне виконання своїх обов'язків у процесі добору кадрів, проходження служби в поліції, професійної підготовки та підвищення кваліфікації кадрів, атестування, формування кадрового резерву, переміщення поліцейських в органах та підрозділах Національної поліції України, перебування поліцейських у розпорядженні, звільнення зі служби в поліції тощо.

Висновки. Слід визнати, що зазначені вище принципи або окремо закріплені в правових нормах, або ж випливають із них. Проте разом із цим необхідно звернути увагу, що наразі у чинному законодавстві України, зокрема й у відомчих нормативно-правових актах МВС України та Національної поліції України, не закріплені такі (спеціальні) принципи, які за своїм характером і змістом безпосередньо враховують специфіку адміністративно-правового регулювання у сфері кадрового забезпечення Національної поліції України:

1) принцип об’єктивності, який спрямований на якнайповніше виключення проявів суб'єктивізму, однобічності й упередженості, а його сутність полягає в забезпеченні встановлення, аналізу та оцінки реальних фактів, які мають значення для прийняття обгрунтованих рішень щодо розв'язання конкретних ситуацій та вчинення подальших дій $[19$, с. 55];

2) принцип неупередженості, що є необхідною умовою належного виконання уповноваженими суб'єктами у сфері кадрового забезпечення Національної поліції України. Під час виконання своїх обов'язків у процесі добору кадрів, проходження служби в поліції, професійної підготовки та підвищення кваліфікації кадрів, атестування, формування кадрового резерву, переміщення поліцейських в органах та підрозділах Національної поліції України, перебування поліцейських у розпорядженні, звільнення зі служби в поліції тощо, уповноважені суб'єкти не повинні виявляти особистої прихильності, небезсторонності або упередженості;

3) принцип підзвітності, який означає, що наділені владними повноваженнями і відповідальністю суб'єкти кадрового забезпечення Національної поліції України зобов'язані аргументовано доповідати та обговорювати результати своєї діяльності як із безпосереднім та вищим керівництвом, так і з громадськістю. Прикладом зазначеного принципу є, зокрема, оприлюднення інформації про переможців конкурсу на посаду поліцейських тощо;

4) принцип плановості та прогнозування, тобто забезпечення логічної послідовної діяльності кожного з учасників процесу добору кадрів, проходження служби в поліції, професійної підготовки та підвищення кваліфікації кадрів, атестування, формування кадрового резерву, переміщення поліцейських в органах та підрозділах Національної поліції України, перебування поліцейських у розпорядженні, звільнення зі служби в поліції тощо. Дані принципи забезпечуються шляхом складання перспективних і поточних планів для ефективного та своєчасного виконання завдань у сфері кадрового забезпечення Національної поліції України з метою попередження, зменшення та ліквідації наявних, потенційних та неминуче виникаючих ризиків щодо неналежного рівня якісного складу поліції, відтоку кваліфікованих кадрів, руйнування професійного ядра у провідних службах поліції тощо;

5) принцип індивідуального підходу, який грунтується на сприйняті кадрового складу (персоналу) як головного надбання Національної поліції України, а кожного працівника - як 
унікальної особистості (індивідуальності) з великим потенціалом. Він спрямований на пошук можливостей врахування індивідуальності кожного працівника та застосування його потенціалу 3 метою ефективного виконання покладених на них обов'язків.

Зважаючи на те, що правові норми, які регулюють кадрову роботу, повинні гармонійно поєднуватися з домінуючими суспільними цінностями та концепцією реформування системи МВС України, а реалізація принципів як основоположних засад кадрового забезпечення Національної поліції України сприятиме успішному здійсненню функцій, вирішенню завдань із забезпечення охорони прав і свобод людини, інтересів суспільства і держави, вважаємо, що доцільно нормативно закріпити такі спеціальні принципи, як: принцип індивідуального підходу та індивідуальної відповідальності; принцип плановості та прогнозування; принцип об'єктивності та неупередженості.

\section{Список використаних джерел:}

1. Андренко С.О. Адміністративно-правові засади кадрового забезпечення органів внутрішніх справ України : дис. ... канд. юрид. наук : 12.00.07 ; ХНУВС. Харків, 2015. 215 с.

2. Словник української мови : в 11 т. / АН УРСР. Інститут мовознавства ; за ред. І.К. Білодіда. Київ : Наукова думка, 1970-1980. Т. 8. 693 с.

3. Юридична енциклопедія : в 6 т. / ред. кол. Ю.С. Шемшученко (голова редкол.) та ін. Київ : Енциклопедія, 2003. Т. 5: П-С. 736 с.

4. Атаманчук Г.В. Теория государственного управления : курс лекцій. Москва : Юрид. лит., 1997.400 с.

5. Колпаков В.К., Кузьменко О.В. Адміністративне право України : підручник. Київ : Юрінком Інтер, 2003. 544 с.

6. Рабінович П.М. Основи загальної теорії права і держави : посіб. для студентів спеціальності Правознавство. Вид. 2- ге, зі змінами і доп. Київ, 1994. 285 с.

7. Саглаєва Н.О. Принципи правового регулювання як самостійна юридична категорія. Актуальні проблеми держави і права. 2012. Вип. 64. С. 110-116.

8. Стеценко С.Г. Адміністративне право України : навч. посіб. Київ : Атіка, 2008. 624 с.

9. Кагановська Т.С. Кадрове забезпечення державного управління в Україні : монографія. Харків : ХНУ ім. В.Н. Каразіна, 2010. 330 с.

10. Шопіна I.M. Адміністративно-правове регулювання управління органами внутрішніх справ України : монографія. Київ : «МП Леся», 2011. 426 с.

11. Про Національну поліцію : Закон України від 2 липня 2015 р. № 580-VIII. Вiдомості Верховної Ради. 2015. № 40-41. Ст. 379.

12. Про державну службу : Закон України від 10 грудня 2015 р. № 889-VIII. Вiдомості Верховної Ради. 2016. № 4. Ст. 43.

13. Державне управління: європейські стандарти, досвід та адміністративне право / Авер'янов В.Б., Дерець В.А., Ославський М.І. та ін. ; за ред. В.Б. Авер'янова. Київ : Юстиніан, 2007.

14. Питання реформування органів внутрішніх справ України : розпорядження Кабінету Міністрів України від 22.10.2014 № 1118-р. Урядовий кур’єр. 2014. № 230.

15. Жмінько В. Можливості та обмеження застосування в Україні міжнародного досвіду реформування правоохоронних органів. Національна безпека і оборона. 2015. № 2-3 (151-152). C. $103-107$.

16. Статус поліції: міжнародні стандарти і зарубіжне законодавство / за заг. ред. О.А. Банчука. Київ : Москаленко О.М., 2013. 588 с.

17. Ківалов С.В., Біла Л.Р. Державна служба в Україні : підручник. Одеса, 2003. 368 с.

18. Новий тлумачний словник української мови (у трьох томах). Том 1: А-К / Укладачі : В.В. Яременко, О.М. Сліпушко. Київ : Вид-во «АКОНІТ», 2006. 926 с.

19. Плугатар Т.А., Скоробагатько О.В. Наукове забезпечення функціонування системи Міністерства внутрішніх справ України: адміністративно-правове регулювання : монографія. Вінниця : ТОВ «Нілан-ЛТД», 2016. 200 с. 